\title{
CACING TANAH (Lumbricus rubellus) SEBAGAI UMPAN ALTERNATIF DAN KARAKTERISTIK KESUKAAN IKAN HASIL TANGKAPAN PANCING ULUR (Hand line) DI PERAIRAN TELUK PALABUHANRATU
}

\section{Earthworm (Lumbricus rubellus) as alternative bait and preference characteristics of fish on hand line fishing operation in Palabuhanratu Bay waters}

Oleh:

\author{
Fazri Saisar $^{1}$, Zulkarnain ${ }^{1}$, Wazir Mawardi ${ }^{1}$, Izza Mahdiana Apriliani ${ }^{2}$ \\ ${ }^{1}$ Departemen Pemanfaatan Sumberdaya Perikanan, FPIK, IPB \\ ${ }^{2}$ Fakultas Perikanan dan Ilmu Kelautan, Universitas Padjadjaran \\ Korespondensi: zulkarnain@apps.ipb.ac.id
}

\begin{abstract}
ABSTRAK
Penelitian ini bertujuan untuk membandingkan hasil tangkapan pancing ulur (hand line) dan karakteristik kesukaannya terhadap penggunaan jenis umpan cacing tanah (Lumbricus rubellus) dan umpan ikan tembang (Sardinella fimbriata) yang biasa digunakan oleh nelayan di Teluk Palabuhanratu sebagai kontrol. Penelitian ini menerapkan metode uji coba penangkapan (experimental fishing) dengan 19 kali ulangan (trip). Komposisi hasil tangkapan terdiri atas 6 jenis ikan dengan jumlah total berjumlah 157 ekor yang didominasi oleh ikan layang (Decapterus kurroides) sebanyak 81 ekor (51,26\%), swanggi (Priacanthus tayenus) sebanyak 42 ekor (26,58\%), kurisi (Nemipterus hexodon) sebanyak 21 ekor (12,29\%), kuwe (Caranx sp) sebanyak 10 ekor (6,33\%), petek (Leiognathus sp) sebanyak 2 ekor (1,26\%) dan barakuda (Sphyraena sp) sebanyak 1 ekor (0,63\%). Perbandingan hasil tangkapan pancing ulur berbeda pada setiap perlakuan dengan menggunakan kedua jenis umpan. Pancing ulur dengan menggunakan umpan ikan tembang memberikan jumlah hasil tangkapan sebanyak 93 ekor (59,2\%). Sedangkan pada pancing ulur menggunakan umpan cacing tanah memberikan hasil tangkapan sebanyak 64 ekor (40,8\%). Perbandingan total hasil tangkapan dari kedua jenis umpan memberikan pengaruh yang signifikan pada taraf $(\alpha)=5 \%$.
\end{abstract}

Kata kunci: cacing tanah, komposisi hasil tangkapan, umpan, pancing ulur

\section{ABSTRACT}

The research was designed in order to compare the catch of hand line and its preference characteristics due to using different baits, i.e earthworm and sardine (Sardinella fimbriata) which ussually used by local fishermen in Palabuhanratu Bay as a control. This research is implementing an experimental fishing with 19 trips. Composition of the catches is consisted by 6 species with total catches of 157 fishes and dominated by layang (Decapterus kurroides) 81 fishes (51.26\%), swanggi (Priacanthus tayenus) with 42 fishes (26.58\%), kurisi (Nemipterus hexodon) with 21 fishes (12.29\%), kuwe (Caranx sp) with 10 fishes (6.33\%), petek (Leiognathus sp) with 2 fishes (1.26\%), and barracuda (Sphyraena $s p$ ) with 1 fishes (0.63\%). Comparison of hand line catches is different by used of two bait types, hand line with sardines bait is giving result of catches by 93 fishes (59.2\%). Meanwhile, in hand line with worm bait is giving result of chatches by 64 fishes (40.8\%). There was significant differences $(\alpha=5 \%)$ in total catches between the hand line with fish bait and worm bait.

Key words: bait, catch composition, earthworm, hand line 


\section{PENDAHULUAN}

Usaha perikanan tangkap di Palabuhanratu didominasi oleh perikanan skala kecil yang menggunakan alat tangkap sederhana dan sebagian besar daerah penangkapan tidak jauh dari Teluk Palabuhanratu. Salah satu alat tangkap skala kecil yang dioperasikan di perairan Teluk Palabuhanratu adalah pancing ulur (hand line). Tercatat pada tahun 2013 pancing ulur merupakan alat tangkap yang dominan di PPN Palabuhanratu, dengan jumlah rata-rata 153 unit (PPN Palabuhanratu 2013).

Pancing ulur termasuk dalam kelompok alat tangkap pancing (Ayodhyoa 1981). Selain konstruksinya sederhana, pengoperasian pancing ulur sangat mudah, tidak memerlukan modal yang besar dan kapal khusus. Pancing ulur merupakan alat tangkap yang mempunyai selektivitas tinggi, karena ukuran mata pancing yang digunakan disesuaikan dengan jenis dan ukuran ikan target penangkapannya. Alat tangkap ini termasuk alat penangkapan ikan yang pasif dan juga ramah lingkungan.

Umpan merupakan salah satu faktor yang berperan penting dalam menunjang keberhasilan operasi penangkapan ikan, khususnya pada alat tangkap bubu (Zulkarnain et al. 2011) dan pancing ulur (Fitriana et al. 2018). Umpan memberikan rangsangan (stimulus) yang bersifat fisika dan kimia yang dapat memberikan respons bagi ikan-ikan tertentu pada proses penangkapan ikan (Sadhori 1985). Pada umumnya ikan-ikan perairan dasar dan karang mendeteksi makanannya menggunakan rangsangan (stimulus) kimia dengan menggunakan sistem penciumannya seperti protein dan asam amino yang tereduksi.

Cacing tanah (Lumbricus rubellus) merupakan hewan tingkat rendah yang tidak memiliki tulang belakang (avertebrata) dan bertubuh lunak. Hewan ini paling sering dijumpai di tanah dan tempat lembab, yang banyak mengandung senyawa organik dan bahan mineral yang cukup baik dari alam maupun dari sampah limbah pembuangan penduduk sebagaimana habitat alaminya (Rukmana 1999). Bagi sebagian orang, cacing tanah masih dianggap sebagai makhluk yang menjijikkan dikarenakan bentuknya, sehingga tidak jarang cacing masih dipandang sebelah mata. Namun terlepas dari hal tersebut, cacing ternyata masih dicari oleh sebagian orang untuk dimanfaatkan secara luas seperti penghasil pupuk organik, bahan pakan ternak, bahan baku obat dan kosmetik, makanan, dan minuman. Kandungan gizi yang terkandung pada cacing tanah sangat tinggi sehingga fungsinya sangat luas untuk dimanfaatkan (Palungkun 1999). Selain fungsi di atas, cacing tanah banyak digunakan sebagai umpan pancing di perairan tawar. Cacing tanah merupakan salah satu umpan alami yang sangat baik untuk menangkap ikan-ikan di perairan tawar. Cacing tanah diduga dapat menjadi umpan alternatif dalam penangkapan ikan di perairan laut karena cacing tanah memiliki kandungan protein yang tinggi melebihi kandungan protein yang ada pada mamalia dan ikan (Palungkun 1999). Selain mengandung protein tinggi cacing tanah mengandung asam amino esensial dan asam amino nonesensial yang sangat lengkap. Kandungan dari asam amino tersebut diidentifikasi sebagai perangsang nafsu makan ikan (Riyanto 2008). Penggunaan cacing tanah sebagai umpan sudah dilakukan untuk menangkap lobster menggunakan bubu lipat (Zulkarnain et al. 2011).

Usaha perikanan pancing ulur dalam perkembangannya tidak banyak mengalami kemajuan yang berarti jika dibandingkan dengan alat tangkap lainnya. Untuk mengatasi hal tersebut, berbagai upaya dan modifikasi dilakukan guna mengoptimalkan dan mengefisiensi produktivitas alat tangkap ini. Salah satunya adalah dengan memodifikasi umpan. Umpan merupakan bagian yang sangat vital dalam proses penangkapan ikan khususnya pada perikanan pancing dan bubu karena ada biaya untuk pengadaannya. Cacing tanah mudah diperoleh di alam dan mudah untuk dibudidayakan, sehingga dapat mengurangi biaya pengeluaran untuk pembelian umpan. Hipotesis yang digunakan dalam penelitian ini adalah apakah terdapat pengaruh penggunaan jenis umpan dalam penelitian terhadap hasil tangkapan.

Tujuan dari penelitian ini adalah membandingkan hasil tangkapan pancing ulur (hand line) dan karakteristik kesukaannya terhadap penggunaan jenis umpan yang berbeda, yaitu cacing tanah 
(Lumbricus rubellus) dan umpan ikan tembang (Sardinella fimbriata) yang biasa digunakan oleh nelayan di Teluk Palabuhanratu.

\section{METODE PENELITIAN}

Pengambilan data di lapangan dilaksanakan pada bulan Mei sampai dengan bulan Juni 2014 yang bertempat di Teluk Palabuhanratu, Kabupaten Sukabumi, Provinsi Jawa Barat.

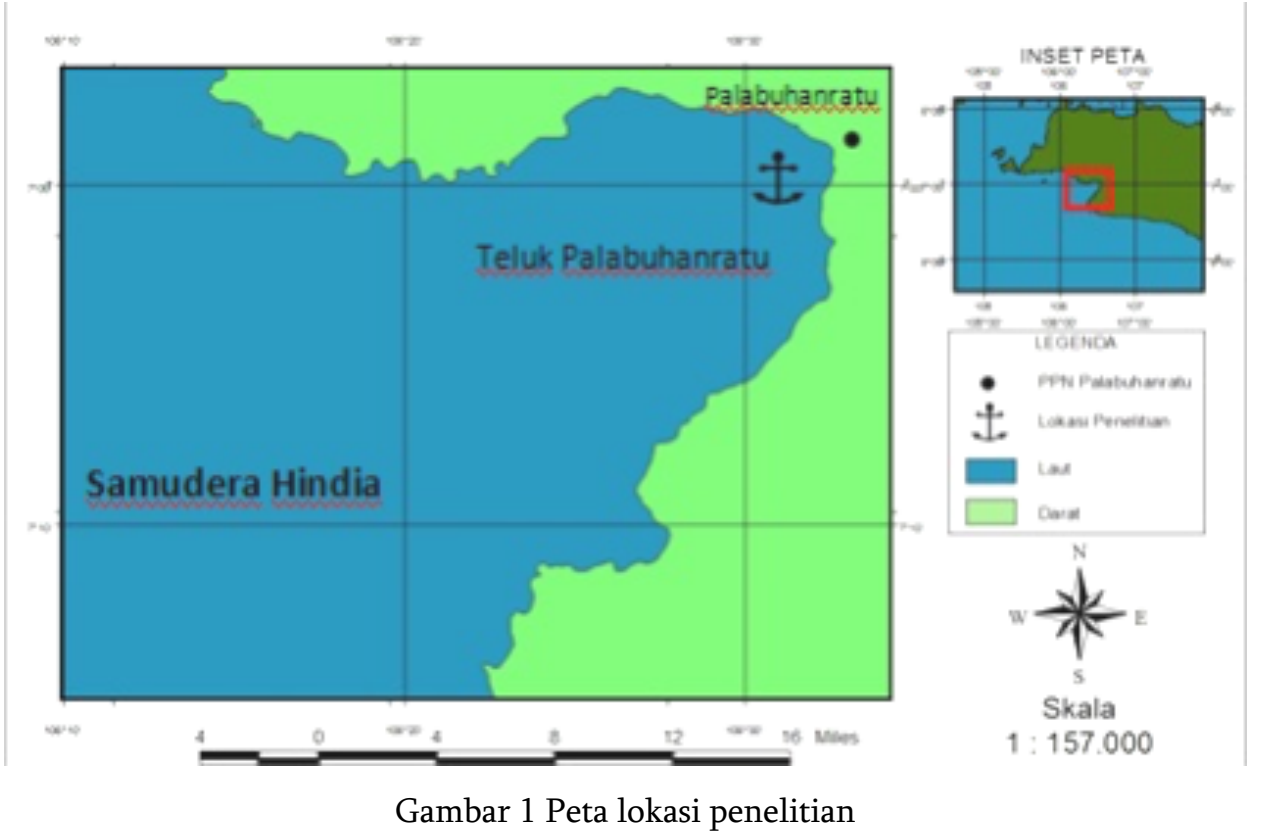

Alat yang digunakan dalam penelitian ini adalah : dua unit alat tangkap pancing ulur (hand line) dengan nomor mata pancing 12, benang ukuran/ nomor 600 dan tali cabang nomor 400; satu unit perahu dengan dimensi panjang $(\mathrm{P}) 7 \mathrm{~m}$, lebar $(\mathrm{L})$ 0,6 m, tinggi (D) 0,7 m; peralatan lain yang digunakan meliputi : timbangan digital untuk mengukur bobot hasil tangkapan, kamera digital untuk pembuatan dokumentasi penelitian, mistar dengan panjang $50 \mathrm{~cm}$, alat bantu menulis berupa papan jalan plastik, software MS. Excel dan SPSS untuk menganalisis data yang diperoleh. Bahan yang digunakan dalam penelitian ini adalah cacing tanah hidup spesies (Lumbricus rubellus) dan ikan tembang (Sardinella fimbriata) yang digunakan sebagai umpan (Gambar 3).

Konstruksi pancing ulur yang digunakan dalam penelitian sama seperti konstruksi pancing ulur yang umumnya digunakan oleh nelayan di Palabuhanratu. Pancing ini ditujukan untuk menangkap ikan dasar. Secara umum konstruksi pancing ulur terdiri dari mata pancing, tali utama (main line), tali cabang (branch line), pemberat, swivel dan penggulung. Spesifikasi alat tangkap pancing ulur yang digunakan dalam penelitian dijelaskan pada Tabel 1 dan konstruksi alat tangkap pancing ulur disajikan pada Gambar 2. 
Tabel 1 Spesifikasi alat tangkap pancing ulur yang digunakan dalam penelitian

\begin{tabular}{lccc}
\hline \multicolumn{1}{c}{ Spesifikasi } & $\begin{array}{c}\text { Jumlah } \\
\text { (unit) }\end{array}$ & Ukuran / No & Bahan \\
\hline Mata pancing & 3 & 12 & kawat baja \\
Tali utama & 1 & 600 & Nylon \\
Tali cabang & 3 & 400 & Nylon \\
Pemberat & 1 & $1 \mathrm{~kg}$ & Timah \\
Swivel & 4 & 7 & stainless steel \\
Penggulung & 1 & Sedang & plastik (pp) \\
\hline
\end{tabular}

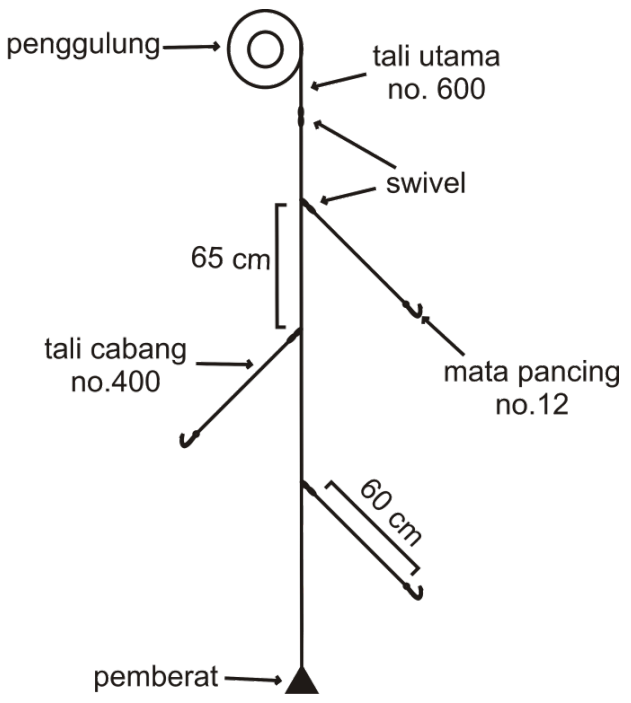

Gambar 2 Konstruksi alat tangkap pancing ulur
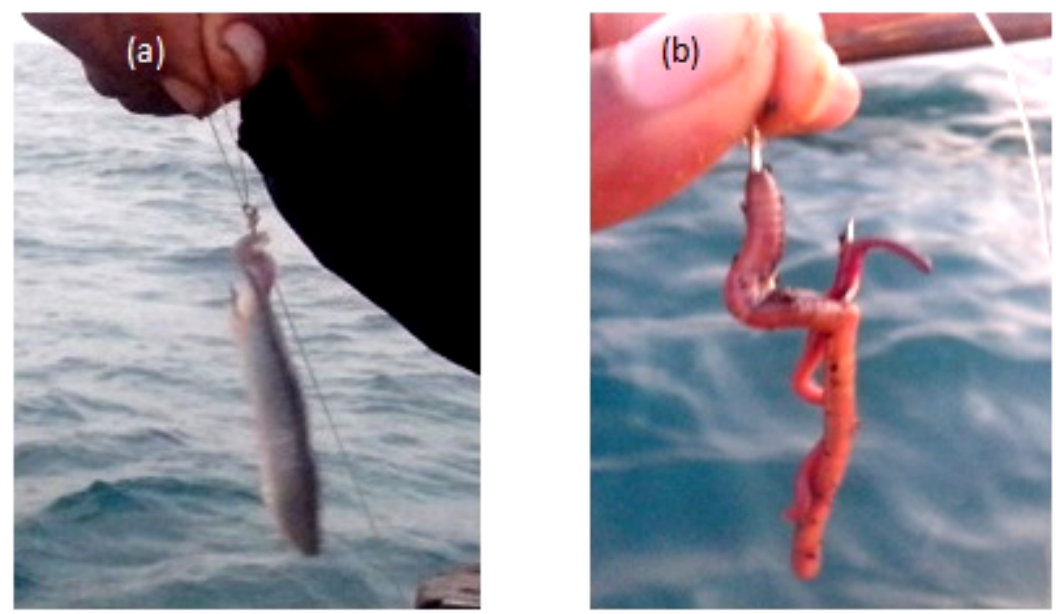

Gambar 3 Pemasangan umpan ikan tembang yang telah disayat (a) dan cacing tanah (b) pada mata pancing.

Perahu yang digunakan dalam penelitian adalah perahu berbahan kayu dengan dimensi panjang (P) $7 \mathrm{~m}$, lebar (L) 0,6 m, depth (D) 0,7 m (Gambar 4). Menggunakan tenaga penggerak berupa mesin tempel yang biasanya disebut mesin gantar oleh para nelayan setempat dengan kekuatan 4 PK. Perahu ini juga memiliki alat penyeimbang pada kedua sisinya yang disebut katir dengan panjang $4,5 \mathrm{~m}$ yang terbuat dari bahan batang bambu. 


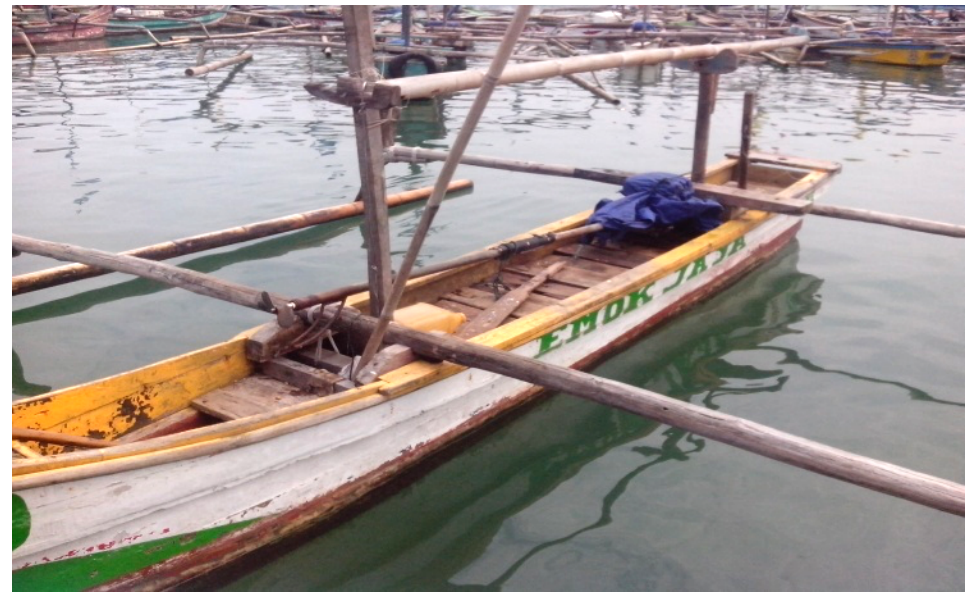

Gambar 4 Perahu yang digunakan dalam penelitian

Metode penelitian ini merupakan uji coba penangkapan ikan (experimental fishing) dengan melakukan kegiatan operasi penangkapan ikan secara langsung di lapangan yaitu mengoperasikan pancing ulur (hand line). Penelitian ini membandingkan hasil tangkapan alat tangkap pancing ulur yang diberikan perlakuan berupa umpan yang berbeda. Umpan yang dibandingkan adalah umpan yang biasa digunakan nelayan yaitu ikan tembang (Sardinella fimbriata) sebagai kontrol yang dibandingkan dengan umpan cacing tanah (Lumbricus rubellus). Penelitian ini dilakukan selama 19 trip sebagai ulangan penelitian.

Kegiatan trip operasi penangkapan ikan dengan pancing ulur dilakukan dalam satu hari (one day trip), dimulai dengan mengadakan beberapa persiapan, seperti persiapan alat pancing, umpan, penyediaan bahan bakar mesin (BBM), penyediaan es curah dan bekal makanan. Setelah persiapan selesai, maka persiapan pemberangkatan perahu menuju fishing ground dilakukan sekitar pukul 05:00 subuh.

Operasi penangkapan dimulai dengan menentukan fishing ground. Sebagian besar nelayan pancing di Palabuhanratu telah memiliki beberapa spot atau daerah biasanya dijadikan fishing ground, dimana di daerah tersebut diduga oleh nelayan setempat memiliki kelimpahan ikan untuk perikanan pancing yaitu daerah Genteng Karet dan Cihaur Kulon. Ke dua daerah perairan tersebut tidak jauh dari PPN Palabuhanratu, dengan menempuh waktu \pm 1 jam perjalanan. Daerah Genteng Karet memiliki kedalaman \pm 75 meter, sedangkan Cihaur Kulon memiliki kedalaman \pm 90 meter. Setelah sampai di fishing ground, maka mesin kapal dimatikan dan jangkar diturunkan agar tidak terbawa oleh arus.

Setelah jangkar diturunkan proses pemancingan (setting) segera disiapkan. Proses setting dimulai dengan menyiapkan alat tangkap dan mengaitkan umpan masing-masing yaitu umpan ikan tembang yang telah disayat dan umpan cacing tanah pada masing-masing mata pancing yang berukuran sama. Setelah umpan dikaitkan lalu mata pancing diturunkan secara vertikal ke dalam air hingga ke dasar perairan dan posisi tali tegak lurus. Pancing kemudian ditarik-tarik perlahan atau disentaksentak, sampai ada ikan yang memakan umpan dan terkait pada mata pancing, lalu tali ditarik (hauling) dengan cepat hingga ikan naik dan dapat diangkat ke atas perahu. Ikan yang didapat dimasukan ke dalam palka perahu. Selanjutnya dilakukan pemasangan umpan dan dilakukan setting kembali. Setelah operasi penangkapan selesai, maka jangkar diangkat dan perahu meninggalkan fishing ground menuju fishing base. Prosedur penelitian dapat dilihat pada Gambar 5. 


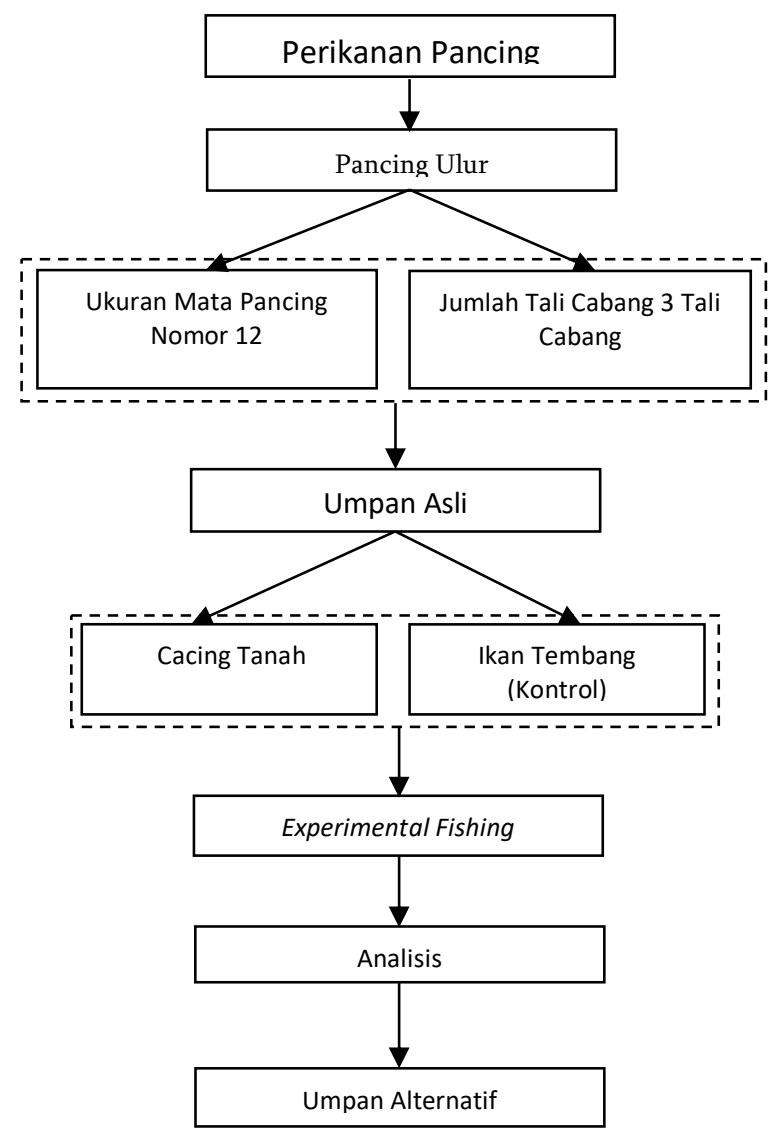

Gambar 5 Prosedur penelitian

Analisis data yang dilakukan pada penelitian ini ada dua macam, yaitu:

1) Analisis deskriptif

Data hasil tangkapan disajikan dalam bentuk tabel beserta diagram, kemudian dianalisis secara deskriptif menurut pokok-pokok bahasan seperti komposisi total hasil tangkapan pancing ulur, hasil tangkapan pancing ulur pada umpan yang berbeda dan jenis ikan dominan hasil tangkapan pada umpan yang berbeda dari 19 kali trip penagkapan.

2) Uji statistik

Dalam penelitian terdapat satu faktor umpan dengan dua macam perlakuan jenis umpan. Umpan dianggap dapat mempengaruhi komposisi hasil tangkapan baik jenis maupun jumlahnya. Uji statistika yang digunakan untuk mengetahui pengaruh perbedaan jenis umpan adalah uji $t$ (Walpole 1995). Uji t yang dilakukan adalah uji t berpasangan (paired $t$ - test) karena penelitian dilakukan secara bersamaan dalam satu perahu, dengan asumsi yang diterapkan selama penelitian adalah : Ikan tujuan penangkapan menyebar merata atau menyebar normal di perairan, dan ikan tujuan penangkapan mempunyai peluang yang sama untuk tertangkap pada kedua umpan. Dasar keputusan yang akan diambil dalam uji $\mathrm{t}$ adalah: Jika $\mathrm{t}$ hitung $>\mathrm{t}$ tabel maka tolak H0, berarti perlakuan dari ke dua jenis umpan memberikan pengaruh yang nyata terhadap hasil tangkapan. Jika $\mathrm{t}$ hitung $<\mathrm{t}$ tabel maka gagal tolak H0, berarti perlakuan dari kedua jenis umpan tidak memberikan pengaruh yang nyata terhadap hasil tangkapan. Hipotesis atau kesimpulan yang akan diambil : H0: Tidak terdapat pengaruh antara kedua umpan terhadap hasil tangkapan. H1: Terdapat pengaruh antara kedua umpan terhadap hasil tangkapan. Analisis dilakukan pada taraf ()$=0,05$. Jumlah ulangan $(\mathrm{n})=19$. Nilai $\mathrm{t}$ dihitung dengan rumus: 


$$
t=\frac{\bar{X}_{1}-\bar{X}_{2}}{\sqrt{\frac{S_{1}^{2}}{n_{1}}+\frac{S_{2}^{2}}{n_{2}}}}
$$

Dimana:

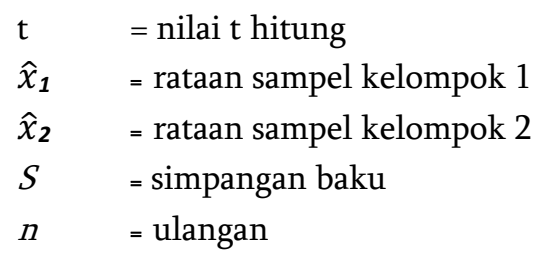

Analisis dilakukan terhadap data total berupa jumlah dan bobot hasil tangkapan dengan menggunakan kedua umpan, total jumlah dan bobot hasil tangkapan dengan menggunakan jenis umpan yang berbeda, dan dominasi masing-masing tiga jenis ikan yang terbanyak ditangkap selama 19 kali trip.

\section{HASIL DAN PEMBAHASAN}

Hasil tangkapan pancing ulur yang diperoleh selama 19 kali operasi penangkapan terdiri dari 6 jenis ikan yaitu layang (Decapterus kurroides), swanggi (Priacanthus tayenus), kuwe (Caranxsp), kurisi (Nemimterus hexodon), barakuda (Sphyraena sp) dan petek (Leiognathus sp). Jumlah total individu hasil tangkapan sebanyak 157 ekor dengan bobot keseluruhan sebesar 39,65 kg. Secara rinci data komposisi total hasil tangkapan disajikan pada Tabel 2.

Tabel 2 Komposisi hasil tangkapan total pancing ulur

\begin{tabular}{rlllrrrr}
\hline \multirow{2}{*}{ No } & \multicolumn{2}{c}{ Jenis Ikan } & Jumlah & \multicolumn{2}{c}{ Bobot } \\
\cline { 2 - 8 } & Nama Lokal & Nama Umum & Nama Latin & Ekor & $\%$ & Kg & $\%$ \\
\hline 1 & Salayang & Layang & (Decapterus kurroides) & 81 & 51,26 & 17,79 & 44,87 \\
2 & Camaul & Swanggi & (Priacanthus tayenus) & 42 & 26,58 & 11,36 & 28,65 \\
3 & Tajug & Kurisi & (Nemipterus hexodon) & 21 & 13,29 & 1,79 & 4,52 \\
4 & Kuwe & Kuwe & (Caranx sp) & 10 & 6,33 & 8,20 & 20,68 \\
5 & Baracuda & Baracuda & (Sphyraena sp) & 1 & 0,63 & 0,41 & 1,04 \\
6 & Petek & Pepetek & (Leiognathus sp) & 2 & 1,26 & 0,08 & 0,20 \\
\hline \multicolumn{2}{r}{ Total } & & 157 & & 39,65 & \\
\hline
\end{tabular}

Layang (Decapterus kurroides) adalah jenis yang paling dominan tertangkap pada penelitian ini. Jumlah ikan layang yang tertangkap sebanyak 81 ekor (51,26\%) dari total hasil tangkapan dengan bobot $17,79 \mathrm{~kg}(44,87 \%)$. Selain hasil tangkapan ikan layang, hasil tangkapan yang cukup dominan adalah ikan swanggi (Priacanthus tayenus) dengan jumlah 42 ekor (26,58\%) dari total hasil tangkapan, dengan bobot $11,36 \mathrm{~kg}(28,65 \%)$. Hasil tangkapan dominan berikutnya adalah ikan kurisi (Nemipterus hexodon) dengan jumlah 21 ekor (12,29\%) dari total hasil tangkapan dengan bobot 1,79 kg.

Hasil tangkapan pancing ulur dihasilkan berbeda-beda pada setiap perlakuan kedua jenis umpan yaitu umpan ikan tembang (A) dan umpan cacing tanah (B). Jumlah hasil tangkapan total (ekor) pada umpan yang berbeda dijelaskan pada Tabel 3 . 
Tabel 3 Jumlah hasil tangkapan pada umpan yang berbeda

\begin{tabular}{llcccc}
\hline \multirow{2}{*}{ No } & \multirow{2}{*}{ Jenis Ikan } & \multicolumn{2}{c}{ Ikan Tembang (Kontrol) } & \multicolumn{2}{c}{ Cacing Tanah } \\
\cline { 3 - 6 } & & Jumlah (ekor) & $\%$ & Jumlah (ekor) & $\%$ \\
\hline 1 & Layang (Decapterus kurroides) & 61 & 75,3 & 20 & 24,7 \\
2 & Swanggi (Priacanthus tayenus) & 17 & 40,5 & 25 & 59,5 \\
3 & Kurisi (Nemipterus hexodon) & 8 & 38,1 & 13 & 61,9 \\
4 & Kuwe (Caranx sp) & 6 & 60 & 4 & 40 \\
5 & Baracuda (Sphyraena sp) & 1 & 100 & - & 0 \\
6 & Petek (Leiognathus sp) & - & 0 & 2 & 100 \\
\hline & Total & 93 & 59,2 & 64 & 40,8 \\
\hline & Rata-rata & 4,8 & & 3,3 & \\
\hline
\end{tabular}

Berdasarkan komposisi total hasil tangkapan (ekor) diperoleh hasil tangkapan umpan tembang lebih tinggi dibandingkan dengan umpan cacing tanah. Pada pancing ulur menggunakan umpan tembang memberikan jumlah total hasil tangkapan sejumlah 93 ekor (59,2\%). Sedangkan pada umpan cacing tanah memberikan jumlah total hasil tangkapan sebanyak 64 ekor (40,8\%). Rata-rata hasil tangkapan (ekor) per trip \pm SE pada umpan tembang adalah 4,8 ekor $\pm 0,54$ dan pada umpan cacing tanah adalah 3,3 ekor $\pm 0,30$ (Gambar 6).

(a)

\section{3}

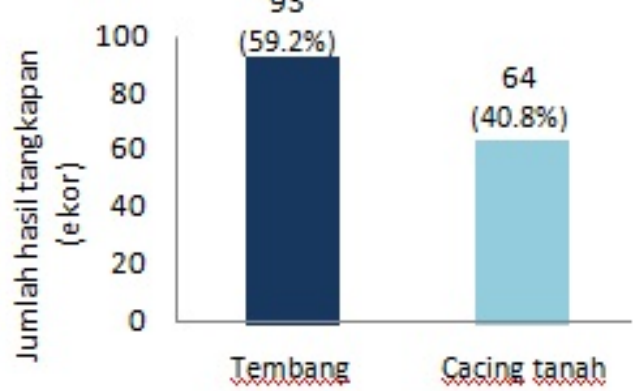

(b)

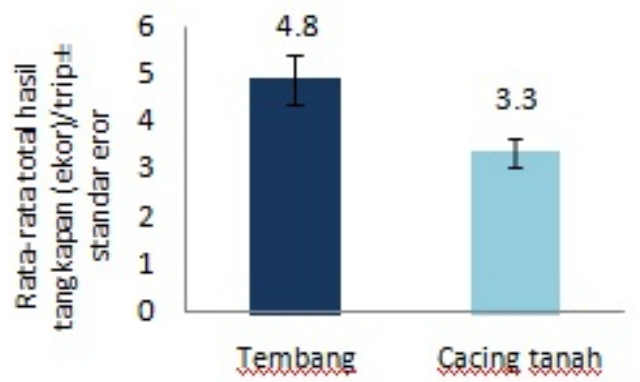

Gambar 6 Jumlah hasil tangkapan (ekor) (a) dan rata-rata hasil tangkapan (ekor) per trip \pm SE (b) antara umpan tembang dan umpan cacing tanah

Berdasarkan analisis menggunakan uji-t statistik pengaruh perbedaan kedua jenis umpan terhadap jumlah hasil tangkapan (total) diperoleh nilai thit sebesar 4,12 dan ttab sebesar 2,10 yang berarti thit $>$ tab. Hal ini menunjukan bahwa perlakuan dari kedua jenis umpan yaitu umpan tembang dan umpan cacing tanah memberikan pengaruh yang nyata terhadap jumlah total hasil tangkapan pada $\operatorname{taraf}(\alpha)=0,05$.

Berdasarkan hasil tangkapan, diperoleh 3 jenis ikan dominan, yaitu ikan layang (Decapterus kurroides), swanggi (Priacanthus tayenus) dan kurisi (Nemimterus hexodon) yang perolehan jumlahnya (ekor) lebih banyak dibandingkan dengan jenis ikan lainnya. Ikan layang pada umpan tembang memperoleh hasil tangkapan sejumlah 61 ekor dibandingkan dengan umpan cacing tanah hanya berjumlah 20 ekor dengan nilai rata-rata hasil tangkapan (ekor) per trip \pm SE pada umpan tembang adalah 3,2 ekor \pm 0,58 dan pada umpan cacing tanah adalah 1,05 ekor \pm 0,24 (Gambar 7). Untuk ikan swanggi pada umpan tembang memperoleh hasil tangkapan sejumlah 17 ekor dibandingkan dengan umpan cacing tanah yaitu berjumlah 25 ekor dengan nilai rata-rata hasil tangkapan (ekor) per trip \pm SE pada umpan tembang adalah 0,94 ekor $\pm 0,26$ dan pada umpan cacing tanah adalah 1,3 ekor \pm 0,24 (Gambar 8). Selanjutnya untuk hasil tangkapan ikan kurisi, umpan tembang memperoleh hasil tangkapan sejumlah 8 ekor dibandingkan dengan umpan cacing tanah yaitu berjumlah 13 ekor dengan 
nilai rata-rata hasil tangkapan (ekor) per trip \pm SE pada umpan tembang adalah 0,4 ekor $\pm 0,13$ dan pada umpan cacing tanah adalah 0,68 ekor $\pm 0,15$ (Gambar 9).

(a)

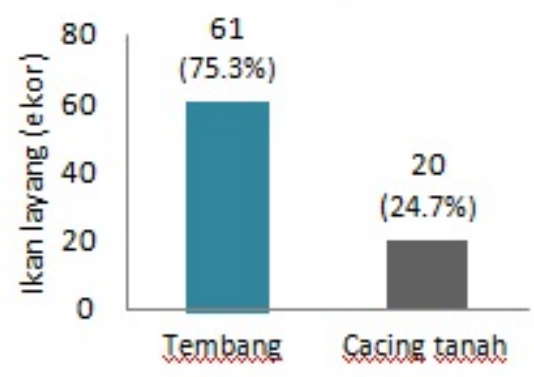

(b)

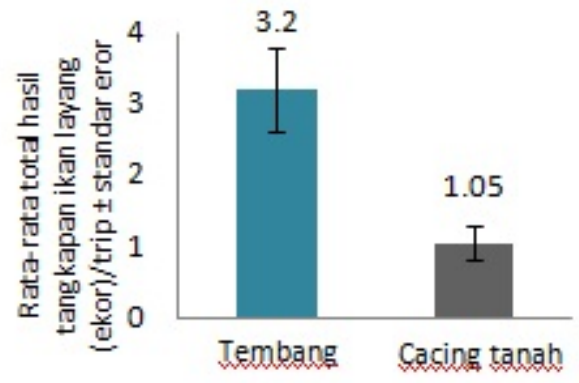

Gambar 7 Jumlah hasil tangkapan ikan layang (ekor) (a) dan rata-rata hasil tangkapan (ekor) per trip \pm SE (b) antara umpan tembang dan umpan cacing tanah

(a)

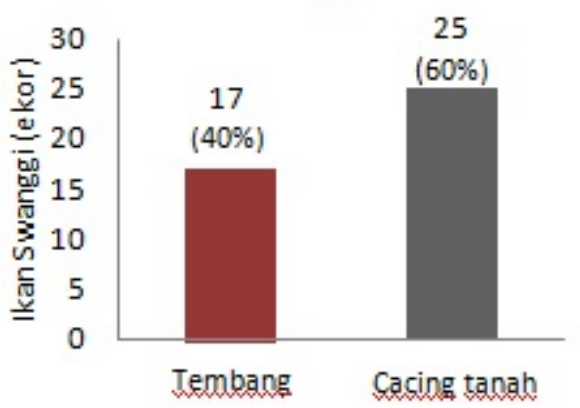

(b)

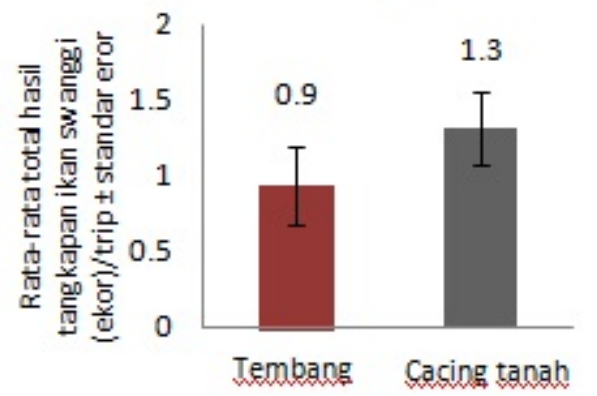

Gambar 8 Jumlah hasil tangkapan ikan swanggi (ekor) (a) dan rata-rata hasil tangkapan (ekor) per trip \pm SE (b) antara umpan tembang dan umpan cacing tanah

(a)

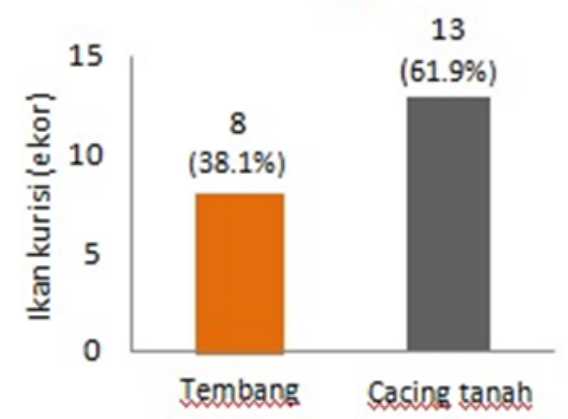

(b)

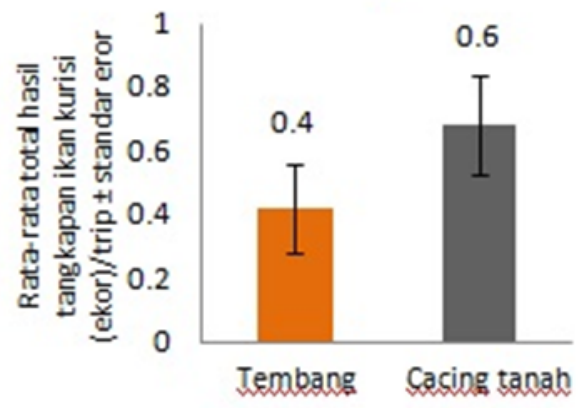

Gambar 9 Jumlah hasil tangkapan ikan kurisi (ekor) (a) dan rata-rata hasil tangkapan (ekor) per trip \pm SE (b) antara umpan tembang dan umpan cacing tanah

Berdasarkan hasil analisis dengan menggunakan uji-t mengenai pengaruh kedua umpan terhadap 3 jenis ikan hasil tangkapan dominan (Tabel 4), umpan tembang dan umpan cacing tanah memberikan pengaruh secara nyata terhadap hasil tangkapan ikan layang, di dapatkan nilai thit sebesar 5,50 dan tab sebesar 2,10. Sedangkan untuk hasil tangkapan ikan swanggi dan kurisi, ke dua jenis umpan yaitu umpan tembang dan umpan cacing tanah tidak memberikan pengaruh yang nyata dengan nilai thit secara berturut-tutut 1,90, 1,56 dan tab sebesar 2,10, 2,10 pada taraf $\alpha=5 \%$. 
Tabel 4 Uji t statistik pengaruh umpan tembang dan umpan cacing tanah terhadap hasil tangkapan ikan dominan

\begin{tabular}{lcccc}
\hline Jenis ikan & thit & tab & $\alpha$ & Hasil analisis \\
\hline Layang & 5,50 & 2,10 & 0,05 & Berpengaruh nyata \\
Swanggi & 1,90 & 2,10 & 0,05 & Tidak bepengaruh nyata \\
Kurisi & 1,56 & 2,10 & 0,05 & Tidak bepengaruh nyata \\
\hline
\end{tabular}

Umpan merupakan salah satu faktor penting untuk menunjang keberhasilan suatu operasi penangkapan, khususnya pada alat tangkap yang bersifat pasif seperti pancing ulur. Menurut Sadhori (1985) umpan merupakan salah satu rangsangan (stimulus) yang bersifat fisika dan kimia yang dapat memberikan respons bagi ikan-ikan tertentu pada proses penangkapan. Pemilihan jenis umpan biasanya disesuaikan dengan kebiasaan makan ikan yang menjadi sasaran penangkapan. Pada umumnya nelayan pancing ulur di Palabuhanratu menggunakan berbagai jenis umpan yang telah disesuaikan dengan tujuan penangkapan, seperti menggunakan umpan asli berupa ikan layang untuk menangkap ikan pelagis besar seperti tuna (Thunus sp.), cakalang (Katsuwonus pelamis), tenggiri (Scomberomoussp.). Ikan tembang (Sardinella sp.), kembung (Rastrelligersp.), petek (Leiognathus sp.), layur (Trichiurus sp.) dan cumi-cumi (Loligo sp.) digunakan untuk penangkapan ikan dasar. Umpan yang digunakan dalam penelitian adalah cacing tanah (Lumbricus rubellus) yang dibandingkan dengan umpan ikan tembang (Sardinella fimbriata) yang biasa digunakan oleh nelayan.

Cacing tanah memiliki potensi untuk dikembangkan dalam usaha penangkapan ikan, salah satunya sebagai umpan karena cacing tanah memiliki kandungan gizi yang cukup tinggi, terutama kandungan proteinnya yang mencapai 64-76\%. Kandungan protein cacing tanah ini ternyata lebih tinggi dari sumber protein lainnya termasuk pada mamalia dan ikan (Palungkun 1999). Selain memiliki protein yang sangat tinggi cacing tanah juga memiliki kandungan asam amino yang paling lengkap, yang terdiri dari alanin, glisin, prolin, tirosin, phenilalanin, lisin, dan histidin serta triptophan dan valin (Palungkun 1999). Asam amino merupakan salah satu substansi kimia yang sangat sensitif terhadap indera pengecap ikan. Alanin, glisin dan prolin merupakan jenis asam amino utama perangsang nafsu makan ikan (Fujaya 2002). Clark (1985) dalam Riyanto (2008) menjelaskan bahwa asam amino yang dapat merangsang penciuman ikan adalah taurine, glutamate, alanine, glicyne, proline dan aspartate. Menurut Engas dan Lokkeborg (1994) dalam Zulkarnain (2011) umpan yang mengandung asam amino diidentifikasi dapat menjadi stimulus dan atraktor makan pada ikan dan crustacea. Hampir semua studi mengenai rangsangan kimia untuk tingkah laku makan ikan menunjukkan bahwa rangsangan makan ikan akan hilang seiring dengan hilangnya kandungan asam amino pada umpan.

Penelitian serupa mengenai umpan cacing tanah telah dilakukan oleh Zulkarnain (2011) dalam disertasinya mengenai efektifitas bubu lipat dengan umpan cacing tanah yang dibandingkan dengan umpan ikan tembang untuk penangkapan spiny lobster dengan hasil penggunaan umpan cacing tanah $(9,2 \%)$ lebih besar dibandingkan dengan yang menggunakan ikan tembang $(3,8 \%)$ artinya penggunaan cacing tanah sangat baik untuk penangkapan spiny lobster. Selain itu Zulkarnain (2011) melakukan pengujian mengenai perubahan kadar protein dan lemak pada kedua umpan. Umpan cacing tanah mengalami penurunan kadar protein yang cukup lambat dibandingkan dengan umpan ikan tembang dan untuk pengujian lemak, umpan cacing tanah mengalami penurunan kadar lemak yang cepat dibandingkan dengan umpan ikan tembang. Kadar protein yang besar dan laju penurunannya yang lambat menunjukkan cacing tanah lebih tahan sebagai umpan dibandingan dengan ikan tembang.

Hasil tangkapan pancing ulur pada dua jenis umpan diperoleh hasil tangkapan dengan menggunakan umpan ikan tembang lebih banyak yaitu sejumlah 93 ekor (59,2\%) dibandingkan dengan umpan cacing tanah berjumlah 64 ekor (40,8\%). Perbedaan jumlah hasil tangkapan pada kedua umpan diduga karena adanya faktor mengenai kebiasaan makan pada masing-masing jenis ikan hasil tangkapan yang berbeda yang sesuai dengan habitatnya. Menurut Purbayanto et al. (2010) rangsangan untuk menarik perhatian ikan ke dalam suatu area operasi penangkapan karena sifat dari jenis ikan itu sendiri 
yang berhubungan dengan natural behavior. Sifat dan rangsangan ini dapat berupa rangsangan fisik dan kimiawi.

Berdasarkan tiga jenis hasil tangkapan ikan dominan yaitu ikan layang, swanggi dan kurisi; ikan layang merupakan hasil tangkapan dengan jumlah terbanyak yang diperoleh pancing ulur dengan menggunakan umpan ikan tembang yang digunakan oleh nelayan. Secara umum ikan ini juga mendominasi jumlah total hasil tangkapan pancing ulur yaitu dengan presentase sebesar 51,26 \% dari total hasil tangkapan. Hal ini diduga karena ikan layang sebagai hasil tangkapan dan ikan tembang sebagai umpan merupakan jenis ikan pelagis sehingga ikan layang telah terbiasa terhadap umpan ikan tembang. Selain itu jenis ikan pelagis diduga lebih mengandalkan indera penglihatan untuk aktifitasnya seperti dalam berburu mangsanya. Jarak penglihatan dipengaruhi oleh keadaan penglihatan dalam air, dimana cahaya dan tingkat kekeruhan sangat berperan penting terhadap indera penglihatan pada ikan (Purbayanto et al. 2010). Ikan tembang juga memiliki bentuk dan warna yang mecolok dibandingkan dengan cacing tanah, sehingga lebih merangsang ikan layang. Sedangkan pada hasil tangkapan ikan swanggi dan kurisi jumlah terbanyak diperoleh pancing ulur dengan menggunakan umpan cacing tanah. Hal ini disebabkan karena ikan swanggi maupun kurisi merupakan jenis ikan demersal. Sebagian besar ikan damersal lebih mengandalkan rangsangan (stimulus) kimia berupa indera penciuman untuk mendeteksi banyaknya makanan yang berada di lingkungannya. Kuatnya bau yang dikeluarkan oleh suatu umpan berdasarkan dari kandungan asam amino yang merupakan bagian dari rangkaian protein yang tereduksi (Taibin 1984 dalam Fitri 2008). Menurut Caprio (1982) dalam Riyanto (2008), kandungan protein dan lemak yang tinggi akan menimbulkan bau yang menyengat dari umpan. Cacing tanah memiliki bau yang lebih kuat dibandingkan dengan ikan tembang, sehingga lebih merangsang ikan swanggi dan kurisi. Asam amino merupakan atraktan (stimuli) yang efektif untuk organ penciuman dan rasa pada ikan (Sola dan Tongiorgi 1998 dalam Fitri 2008).

Berdasarkan uji-t statistik, kedua umpan memberikan pengaruh secara nyata terhadap hasil tangkapan ikan layang. Dalam hal ini umpan yang paling baik digunakan untuk menangkap ikan layang adalah umpan ikan tembang yang merupakan umpan standar dengan nilai rata-rata per trip 3,32 ekor \pm 2,5 untuk pancing ulur dengan menggunakan umpan ikan tembang dan 1,05 ekor $\pm 1,07$ untuk pancing ulur menggunakan umpan cacing tanah. Sedangkan pada ikan swanggi dan kurisi, kedua umpan tidak memberikan pengaruh yang nyata. Berdasarkan nilai rata-rata hasil tangkapan ikan swanggi per trip, pancing ulur menggunakan umpan cacing tanah $(1,3$ ekor $\pm 1,05)$ lebih baik dibandingkan menggunakan umpan ikan tembang $(0,94$ ekor $\pm 1,1)$. Demikian juga pada hasil tangkapan ikan kurisi per trip, pancing ulur menggunakan umpan cacing tanah $(0,68$ ekor $\pm 0,67)$ lebih baik dibandingkan dengan menggunakan umpan ikan tembang $(0,4$ ekor $\pm 0,6)$.

Interaksi antara ikan hasil tangkapan memiliki peluang yang sama untuk memilih kedua jenis umpan karena kedua alat tangkap pancing ulur yang dioperasikan berada pada kedalaman yang sama, yaitu diturunkan hingga ke dasar perairan dengan kedalaman mencapai 75-90 meter. Tertangkapnya ikan layang yang merupakan jenis ikan pelagis diduga karena tingkah laku ikan layang yang cenderung bergerak ke dasar perairan pada pagi hingga siang hari untuk mencari makanan di dasar perairan. Menurut De Bruin et al (1995) dalam Fitriyanti (2000) menyatakan bahwa ikan layang merupakan ikan pelagis, hidup di kolom air, di permukaan atau di perairan dangkal dengan kedalaman 20-200 m. Pada siang hari cenderung bergerak ke dasar perairan dan bergerak ke permukaan air pada malam hari karena adanya sifat fototaksis akibat cahaya yang dikeluarkan oleh plankton. 


\section{KESIMPULAN DAN SARAN}

Komposisi Hasil tangkapan dari 19 kali trip terdiri atas 6 jenis, pada pancing dengan umpan ikan tembang memberikan jumlah total hasil tangkapan sebanyak 93 ekor $(59,2 \%)$ dengan bobot 22,49 $\mathrm{kg}$ $(58,7 \%)$. Sedangkan pada umpan cacing tanah memberikan jumlah total hasil tangkapan sebanyak 64 ekor $(40,8 \%)$ dengan bobot $15,8 \mathrm{~kg}(41,3 \%)$. Kedua umpan memberikan pengaruh yang nyata terhadap jumlah hasil tangkapan (total).

Berdasarkan jenis ikan dominan yang tertangkap, umpan ikan tembang lebih disukai oleh ikan layang yang merupakan jenis ikan permukaan (pelagis). Sementara umpan cacing tanah lebih disukai oleh ikan swanggi dan ikan kurisi yang merupakan jenis ikan dasar (demersal). Kedua jenis umpan tidak memberikan pengaruh yang nyata terhadap hasil tangkapan ikan swanggi dan kurisi. Cacing tanah dapat digunakan sebagai umpan alternatif yang sangat baik untuk menangkap jenis ikan demersal.

\section{DAFTAR PUSTAKA}

Ayodhyoa A U. 1981. Metode Penangkapan Ikan. Bogor (ID): Yayasan Dewi Sri.

Fitri ADP. 2008. Respons Penglihatan dan Penciuman Ikan terhadap Umpan Terkait dengan Efektivitas Penangkapan [Disertasi]. Bogor (ID): Departemen Pemanfaatan Sumberdaya Perikanan, Fakultas Perikanan dan Ilmu Kelautan, Institut Pertanian Bogor.

Fitriana MF, Zulkarnain, Yusfiandayani R, Apriliani IM. 2018. Penggunaan cacing tanah (Lumbricus rubellus) sebagai umpan alternatif pada pancing ulur yang dioperasikan malam hari di teluk Palabuhanratu. Jurnal Akuatika Indonesia. 3(2):119-126.

Fitriyanti. 2000. Inventarisasi Parasit Metazoa pada Ikan Kurisi (Nemipterus sp), Ikan Swanggi (Priachantus sp) dan Ikan Layang (Decapterus sp) Dari Tempat Pelelangan Ikan Palabuhanratu Jawa Barat [Skripsi]. Bogor (ID): Departemen Budidaya Perairan, Fakultas Perikanan dan Ilmu Kelautan, Institut Pertanian Bogor.

Fujaya Y. 2002. Fisiologi Ikan. Dasar Pengembangan Teknologi Perikanan. Fakultas Ilmu Kelautan dan Perikanan. Universitas Hasanuddin. Makasar dengan Direktorat Jenderal Pendidikan Tinggi, Departemen Pendidikan Nasional Republik Indonesia. 204 hal.

Handriana J. 2006. Evektivitas Rumpon Laut Dalam Terhadap Pengoperasian Pancing Tonda di Perairan Palabuhanratu, Sukabumi Jawa Barat [Skripsi]. Bogor (ID): Departemen Pemanfaatan Sumberdaya Perikanan, Fakultas Perikanan dan Ilmu Kelautan, Institut Pertanian Bogor.

Palungkun R. 1999. Sukses Beternak Cacing Tanah (Lumbricus rubellus). Jakarta. Penebar Swadaya. Hlm 5-20.

[PPNP] Pelabuhan Perikanan Nusantara Palabuhanratu. 2014. Statistik Perikanan Pelabuhan Perikanan Nusantara tahun 2013. Sukabumi (ID): PPN Palabuhanratu.

Purbayanto A, Riyanto M, Fitri ADP. 2010. Fisiologi dan Tingkah Laku Ikan Pada Perikanan Tangkap. Bogor. IPB Press. Hal 7.

Riyanto M. 2008. Respon Penciuman Ikan Kerapu Macan (Epinephelus fuscoguttatus) Terhadap Umpan Buatan [Tesis]. Bogor (ID): Program Pascasarjana, Institut Pertanian Bogor.

Rukmana R. 1999. Budidaya Cacing tanah. Yogyakarta. Kanisius. Hlm 14-20.

Sadhori. 1985. Teknologi Penangkapan Ikan. Jakarta. CV. Yasaguna.

Walpole RE. 1995. Pengantar Statistik. Sumantri B, penerjemah. PT. Gramedia Pustaka Utama. Jakarta. Terjemahan dari: Introduction to Statistics. $515 \mathrm{hlm}$. 
Zulkarnain, Baskoro MS, Martasuganda S, Monintja DR. 2011. Pengembangan desain bubu lobster yang efektif. Buletin PSP. 16(2):45-47.

Zulkarnain, Baskoro MS, Martasuganda S, Monintja DR. 2011. Efektivitas bubu lipat modifikasi dan penggunaan umpan cacing tanah (Lumbricus rubellus) pada penangkapan spiny lobster (Panulirus spp.) di perairan pesisir timur teluk pelabuhanratu Jawa Barat. Buletin PSP. 16(3):239-252.

\section{LAMPIRAN}

Dokumentasi kegiatan experimental fishing

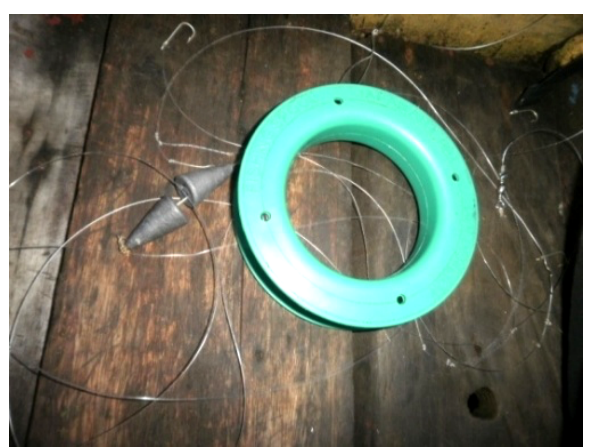

Pancing ulur yang digunakan

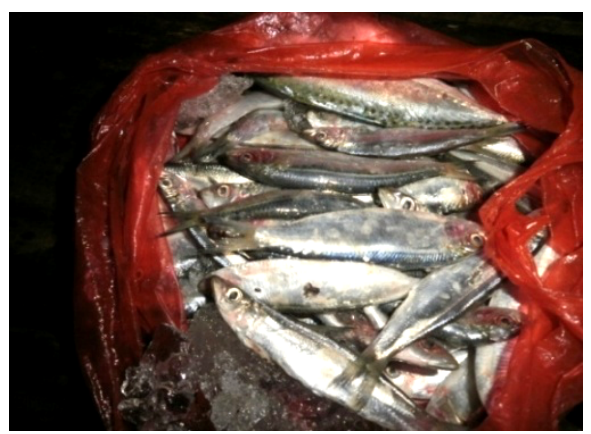

Umpan ikan tembang segar

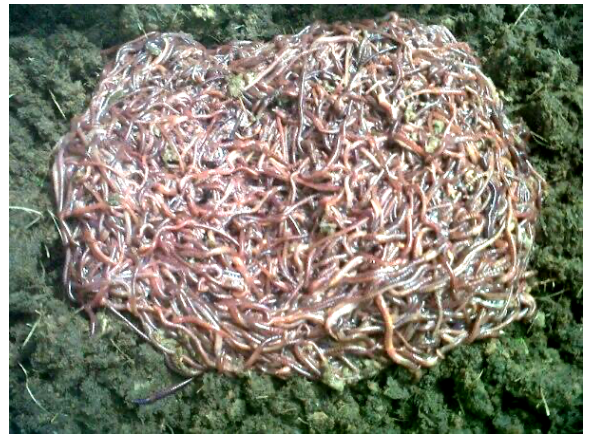

Umpan cacing tanah

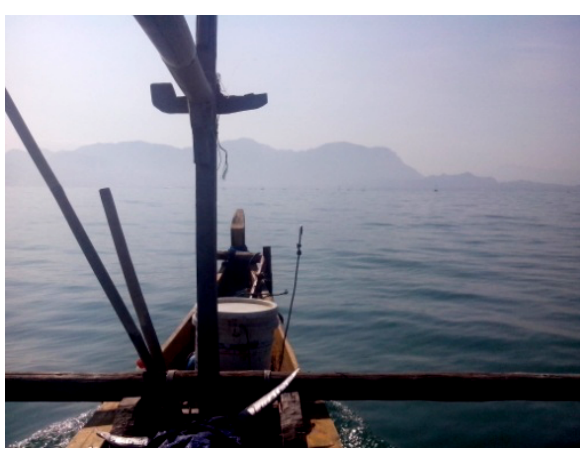

Menuju fishing ground

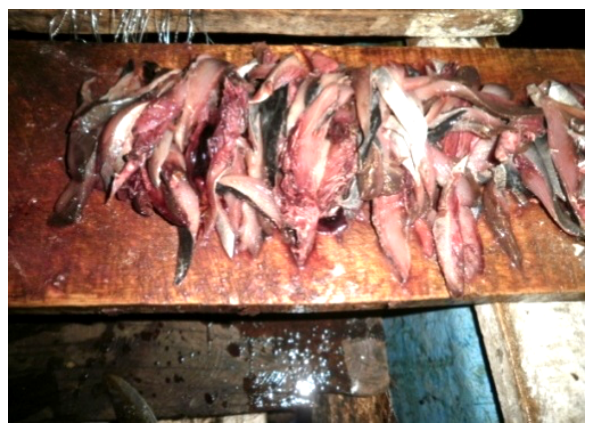

Ikan tembang yang telah disayat

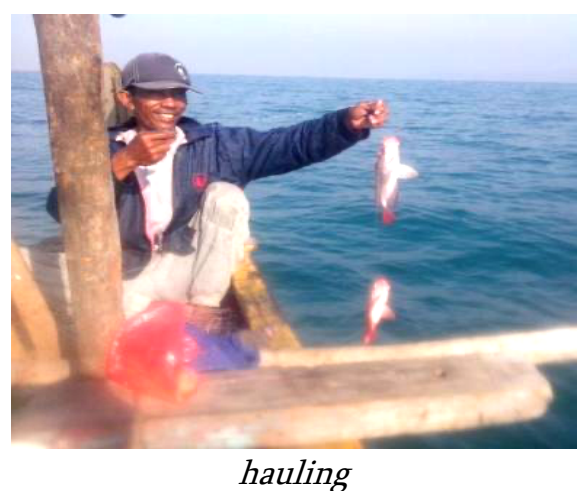


Dokumentasi kegiatan experimental fishing

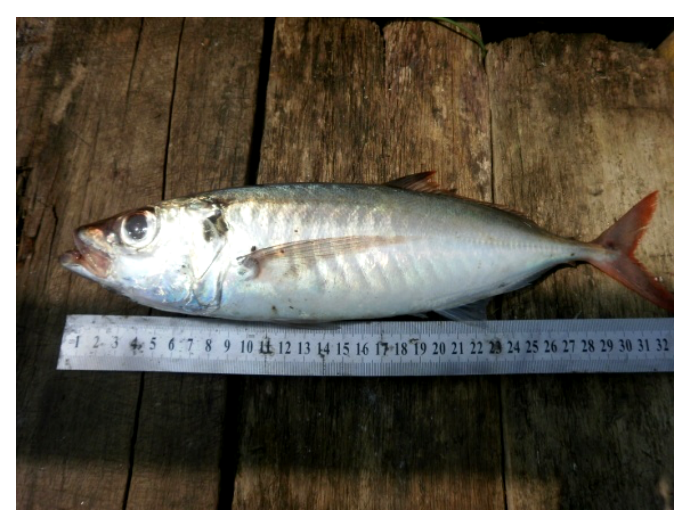

Layang (Decepterus kurroides)

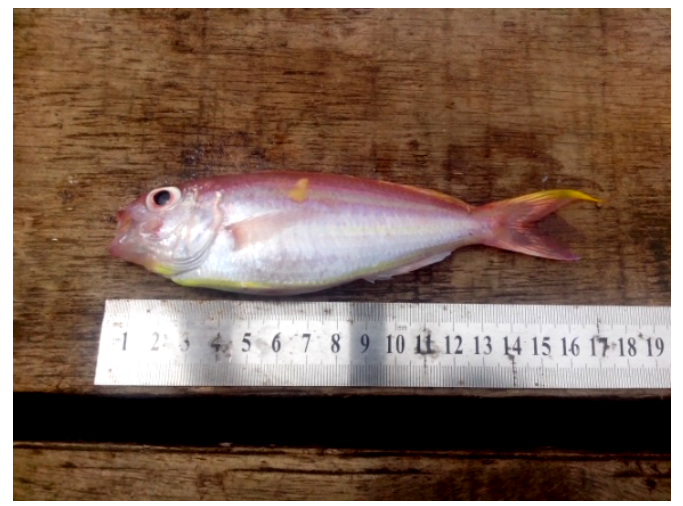

Kurisi (Nemipterus hexodon)

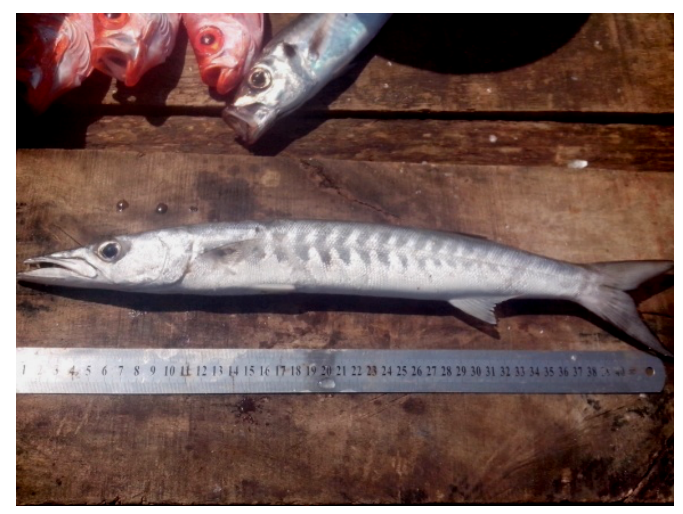

Barracuda (Sphyraena sp.)

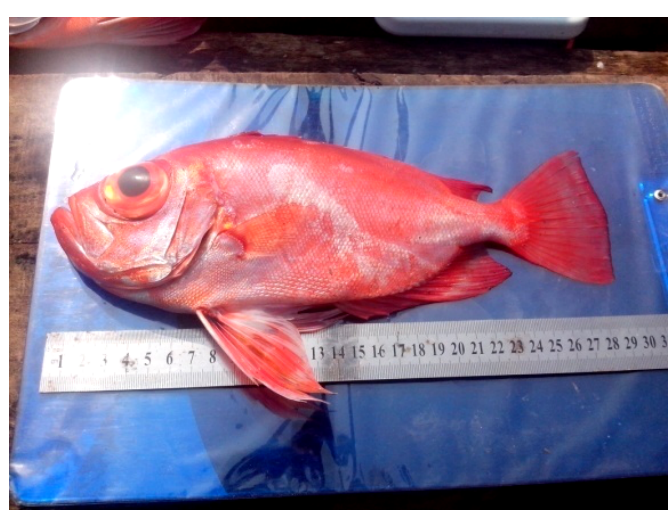

Swanggi (Priachantus tayenus)

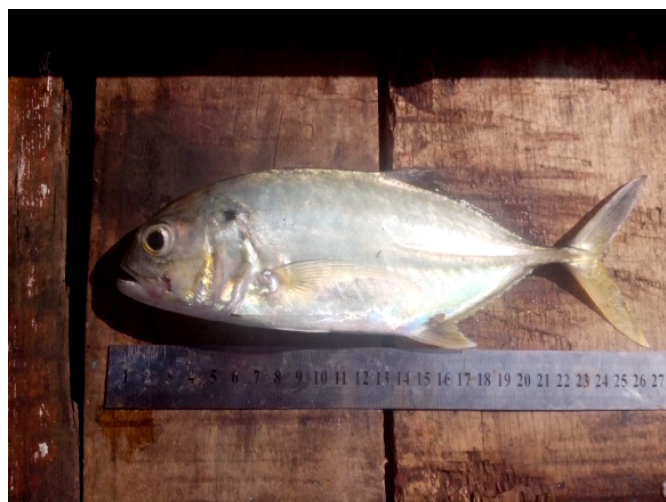

Kuwe (Caranx sp.)

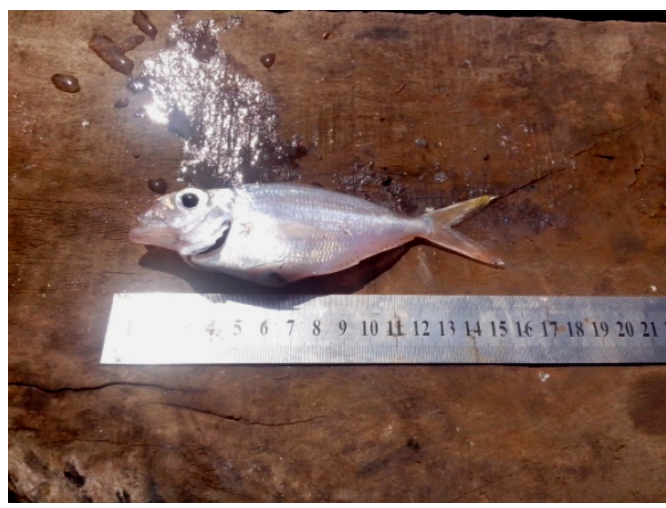

Petek (Leiognathus sp.) 